\title{
Steristrips, an Appropriate Means for Neck Skin Apposition?
}

\section{R Sheikh1, M Asad, A Hart-Pinto, J Beckett, D Houghton, U Alkhaddour, T Kanzara, J Tahery*}

\author{
${ }^{1}$ Corresponding Author \\ *Operating Consultant Surgeon \\ ENT Department, \\ The Countess of Chester Hospital NHS Foundation Trust \\ Liverpool Road \\ Chester CH2 1UL \\ United Kingdom
}

Consent:

As this is a retrospective review, consent was not taken and/or necessary.

Conflict of Interests:

The authors have no conflict of interests or financial interest, real or perceived, to disclose.

\section{Introduction:}

Approximation or apposition of the skin after clean surgeries in the neck without tension leads to eventual closure unless infection or dehiscence occurs. It is customary to close subcutaneous tissue with absorbable sutures while the skin is dealt with non-absorbable sutures or clips. We aim to establish that post minimally invasive neck surgery, steristrips alone can approximate the skin and result in good wound closure.

\section{Methods:}

Using the Southampton grading scheme for surgical wounds, we aimed to assess the records of 70 patients retrospectively by analysing assessment of their post-operative wounds a week after the surgery. Thirty-five subjects, randomly selected, had skin closed with nonabsorbable sutures while the remaining 35 subjects had skin closed with steristrips alone. Length of incision was documented. Statistical analysis was done using SPSS software. Cumulative scores were assessed using Chi-square statistic and a p-value $[<0.05]$ was generated to attain statistical significance.

Tables \& Results:

\begin{tabular}{|c|c|c|c|}
\hline \multicolumn{2}{|c|}{ Variable } & \multicolumn{2}{|l|}{ Value } \\
\hline Age & $\begin{array}{l}\text { Mean } \\
\text { Range }\end{array}$ & \multicolumn{2}{|c|}{$\begin{array}{l}53.47[ \pm 14.63(1 S D)] \text { years } \\
23-78 \text { years }\end{array}$} \\
\hline Sex & $\begin{array}{l}\text { Male } \\
\text { Female }\end{array}$ & \multicolumn{2}{|c|}{$11(15.71 \%)$} \\
\hline \multirow{2}{*}{\multicolumn{2}{|c|}{$\begin{array}{l}\text { Table } 2 \text { - Sutures vs Steristrips } \\
\text { Variable }\end{array}$}} & \multicolumn{2}{|c|}{ Patients [ $\mathrm{n}=70]$} \\
\hline & & Sutures & Steristrips \\
\hline \multicolumn{2}{|l|}{$\mathrm{n}$} & 35 (50\%) & $35(50 \%)$ \\
\hline \multicolumn{2}{|c|}{ Incision size } & $4.7[ \pm 1.54(1 \mathrm{SD})] \mathrm{cm}$ & $4.3[ \pm 1.34(1 \mathrm{SD})] \mathrm{cm}$ \\
\hline \multirow{2}{*}{\multicolumn{2}{|c|}{ Southampton Scores }} & $\mathrm{n}$ & $\mathrm{n}$ \\
\hline ( & & 23 & 26 \\
\hline \multirow{2}{*}{\multicolumn{2}{|c|}{$\begin{array}{l}\text { la } \\
\text { lb }\end{array}$}} & 6 & 8 \\
\hline & & 4 & 1 \\
\hline \multicolumn{2}{|l|}{ Illb } & 2 & 0 \\
\hline
\end{tabular}

Chi-square statistic calculated 0.6122 . The $p$-value generated $=.43$. This result is not significant at $p<.05$.

\section{Discussion:}

Steristrips are known to enhance wound healing through rapid development of wound tensile strength. As opposed to sutures, they not only save operating time but also prevents possible infections caused by sutures. Their application can give results similar if not better than subcuticular sutures.

Our results from 70 patients do not show any statistical or clinical difference between patients who underwent application of steristrips versus old fashioned sutures to the skin.

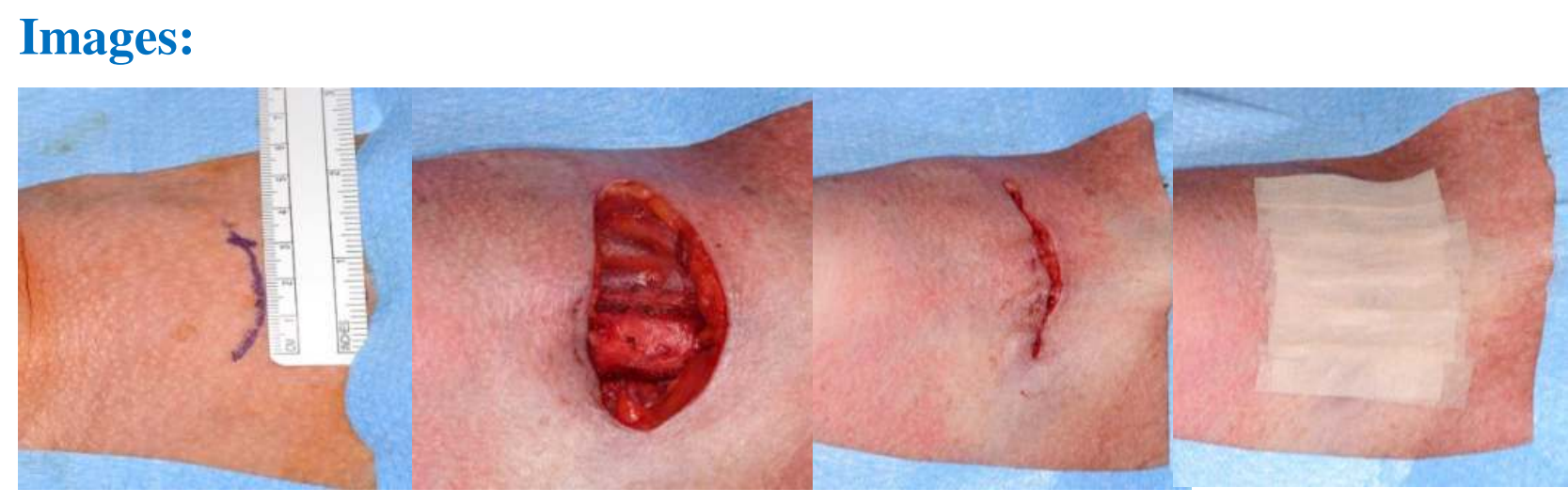

A small incision is followed by subcutaneous sutures, to approximate the platysma muscle, and application of steristrips.

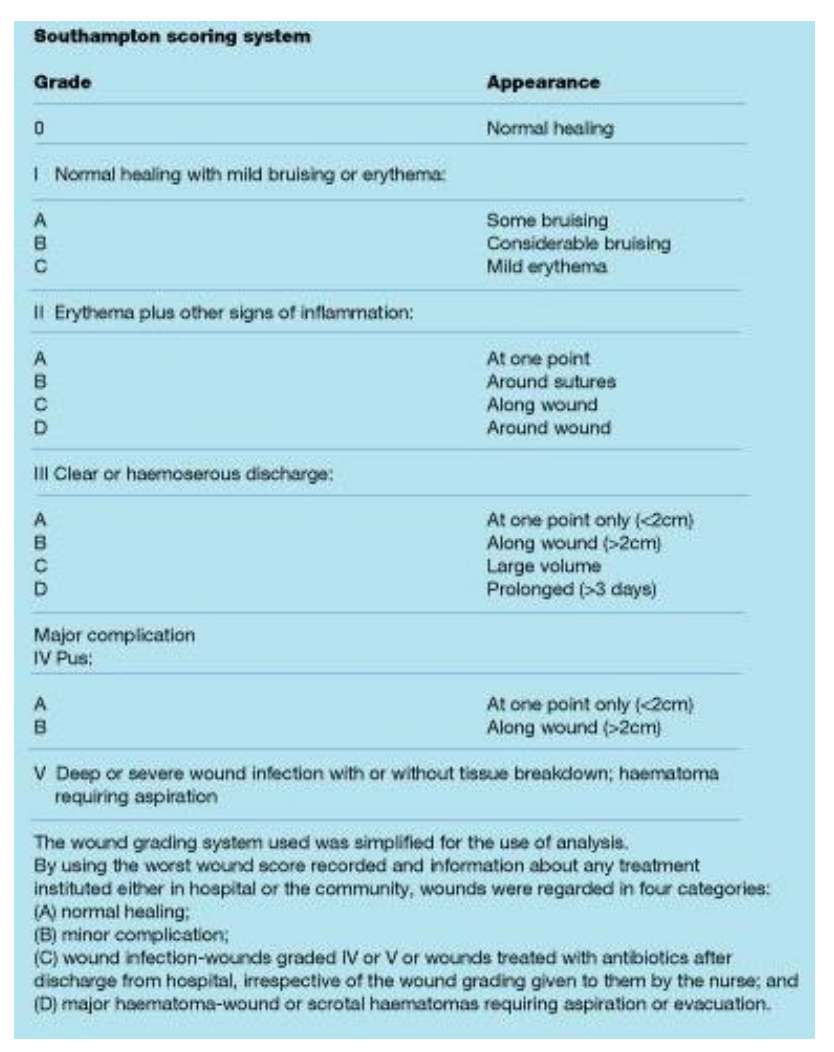

The Southampton scoring system to assess post operative wounds

\section{Limitations:}

We admit that a retrospective study with a limited sample size has the disadvantage of researchers bias as well as reliance on documentation which at times is poor. A selection bias is also possible considering we selected patients who had good documentation of the post operative wound a week after their surgery. We recommend a prospective study with a larger sample size to put more weight into the study.

\section{Conclusion:}

Steristrips alone are sufficient to close skin incisions approximately $5 \mathrm{~cm}$ after clean surgeries in the neck specifically when the underlying tissues including the platysma muscle have been approximated well.

References:

1. Bailey IS, Karran SE, et al. Community surveillance of complications after hernia surgery. BMJ. 1992; 304: 469-471. (Table I, page 470) 2. Thio D, Savage J, Hilton M. Closure of the post-auricular wound in middle ear surgery - a technique using a folded drape and steristrips. Clin Otolaryngol. 2008 Apr;33(2):174.

3. Sikand M, Murtaza A, Desai VV. Healing of arthroscopic portals: a randomised trial comparing three methods of portal closure. Acta Orthop Belg. 2006 Oct;72(5):583-6.

4. Mattick A, Clegg G, Beattie T, Ahmad T. A randomised, controlled trial comparing a tissue adhesive (2-octylcyanoacrylate) with adhesive strips (Steristrips) for paediatric laceration repair. Emerg Med J. 2002. Sep;19(5):405-7.

5. Maharaj D, Sharma D, Ramdass M, Naraynsingh V. Closure of traumatic wounds without cleaning and suturing. Postgrad Med J. 2002 May;78(919):281-2. 